\title{
2: $177903035-177909534$
}

National Cancer Institute

\section{Source}

National Cancer Institute. 2:177903035-177909534. NCI Thesaurus. Code C42480.

Physical location of HNRPA3_Gene 